\title{
MENINGKATKAN KOMPETENSI PEDAGOGIS PENDIDIK DAN HASIL BELAJAR EKONOMI MELALUI GUIDE DISCOVERY LEARNING MODEL
}

\author{
Dewi Koryati, Universitas Sriwijaya \\ dekor.unsri@gmail.com
}

\begin{abstract}
ABSTRAK
Tujuan penelitian ini untuk meningkatkan kompetensi pedagogis pendidik dan hasil belajar peserta didik pada mata pelajaran ekonomi melalui Model Guide Discovery Learning. Metode penelitian menggunakan desain Penelitian Tindakan Kelas yang dilakukan secara bertahap dalam kegiatan plan, act, and observe, serta reflect (action research spiral-cycle). Pelaksanaan tindakan dilakukan dalam 8 kali pertemuan di kelas X IPS-3. Selain itu digunakan juga kelas X IPS-4 untuk pengujian hasil latihan terbimbing penerapan model discovery learning pada pendidik. Data dikumpulkan melalui teknik observasi, wawancara, jurnal refleksi guru, dan test hasil belajar. Selanjutnya data tersebut dianalisis dengan menggunakan model interaktif analisis data, yang terbagi dalam 3 tahap analisis, yaitu; data reduction, data display, dan conclusion drawing. Hasilnya, kompetensi pedagogis pendidik dan hasil belajar peserta didik meningkat.
\end{abstract}

Kata Kunci: Guide Discovery Learning, Kompetensi Pedagogis, Hasil Belajar.

\section{ABSTRACT}

The purpose of this research is to improve the pedagogic competence of educators and student's learning outcomes on economic subjects through the model Guide Discovery Learning. The research method uses the design of class action research that is done gradually in the plan, ACT, and observe activities, as well as the reflect (action research spiral-cycle). Implementation of the action is done in 8 meetings in class XIPS-3. Also, it used as Class X IPS-4 for testing training results guided by implementing discovery learning models on educators. Data collected through observation techniques, interviews, teacher reflection journals, and test learning outcomes. Furthermore, the data is analyzed using an interactive model of data analysis, which divided into three stages of the investigation, namely; Data reduction, display data, and conclusion drawing. As a result, the pedagogic competence of educators and students' learning outcomes increases.

Keywords: Guide Discovery Learning, Competency Pedagogic, Learning Outcomes. 


\section{PENDAHULUAN}

Analisis hasil Ujian Nasional (UN) yang diterbitkan oleh Pusat Penilaian Pendidikan (Puspendik) Balitbang Kemdikbud (2019), menunjukkan capaian nilai UN mata uji ekonomi setiap tahun berubah-ubah sesuai dengan tingkat kesulitan soal UN. Berdasarkan hasil UN SMA tahun 2019, Direktorat Pembinaan SMA telah menginformasikan beberapa mata pelajaran dengan hasil UN kategori kurang atau nilai mata pelajaran yang diujikan di bawah 55, salah satunya adalah mata pelajaran ekonomi. Untuk wilayah Sumatera Selatan rerata capaian nilai UN pada mata uji ekonomi dari 740 SMA/MA (38.036 peserta didik) adalah 46,02 (Pusat Penilaian Pendidikan, Kementerian Pendidikan dan Kebudayaan, 2019).

Terkait laporan hasil UN 2019 tersebut, informasi yang diperoleh dari beberapa resume pada setiap pertemuan pembelajaran yang dibuat guru ekonomi di kota Palembang, disimpulkan bahwa penyebab permasalahan hasil belajar ekonomi peserta didik rendah, adalah; 1) peserta didik terpaku pada materi yang ada di buku pegangan siswa; 2) Guru sudah menerapkan pembelajaran aktif di kelas, salah satunya adalah model discovery learning, namun sebagian peserta didik pengetahuannya masih sebatas pada menghafalkan materi yang ada dalam buku cetak, belum mampu memberikan contoh atau menjelaskan konsep berdasarkan pemahaman sendiri. Kondisi tersebut terlihat dari jawaban peserta didik jika diberikan soal yang berbeda dengan buku meskipun masih dalam konteks yang sama mereka belum dapat menjawabnya dengan benar; 3) peserta didik jarang mengajukan pertanyaan, walaupun guru sering meminta mereka bertanya jika ada hal-hal yang belum jelas atau kurang paham; 4) kurangnya keberanian peserta didik untuk mengemukakan gagasan/ pendapat dalam pembelajaran.

Dua permasalahan di atas, menunjukkan bahwa upaya guru untuk meningkatkan hasil belajar dengan menerapkan model-model pembelajaran aktif di kelas, belum berdampak optimal pada peningkatan mutu hasil belajar, sikap, dan kemandirian belajar peserta didik. Berbeda dengan pendapat Silberman (2004) yang dikutip dari studi literatur yang dilakukan Pyng (2011) dikatakan bahwa; "...hanya pembelajaran yang bersifat aktif dapat membuahkan hasil belajar yang benar dan bersifat kekal". Aktivitas-aktivitas dalam pembelajaran aktif akan membawa keterlibatan peserta didik dalam proses pembelajaran, sehingga mereka berusaha menggunakan pikirannya untuk mengkaji ide, menyelesaikan masalah dan menerapkan apa yang dipelajari. Bahkan untuk pendidikan ekonomi, prinsip pembelajaran aktif selalu diutamakan dalam beberapa kajian tentang proses dan hasil belajar ekonomi peserta didik, antara lain oleh Carlson \& Velenchik (2006), Bartlett (2006), dan Buckles \& Hoyt (2006) dalam (Pyng, 2011).

Kembali pada masalah capaian nilai UN dan aktivitas peserta didik dalam proses belajar yang dihadapi guru ekonomi di Provinsi Sumatera Selatan, Wilkins (1990) menyebutkan Guide Discovery Learning (GDL) merupakan salah satu model pembelajaran yang menggunakan proses berpikir induktif dan baik untuk meningkatkan aktivitas peserta didik, karena menurutnya model GDL adalah "the process by which repeated experience is refined to produce generalisable knowledge" (Wilkins, 1990). Lebih lanjut 
dijelaskannya bahwa melalui bimbingan yang benar dari guru dalam mengarahkan pembelajaran, maka peserta didik akan dapat kesempatan untuk belajar bagaimana belajar (learn how to learn) (Wilkins, 1990). Pendapat Wilkins ini didukung oleh Prince dan Felder (2006) yang dikutip dari Yuliana, dkk. (2017) yang menyebutkan bahwa GDL memungkinkan peserta didik dapat mandiri melakukan eksperimen dan menarik kesimpulan, memberikan pendapat dan intuisi. Guru sebagai fasilitator yang akan membantu dan membimbing peserta didik dalam proses pembelajaran ketika dibutuhkannya. Mereka (peserta didik) didorong untuk mengetahui ide, konsep, dan keterampilan sendiri, sehingga proses pembelajaran akan menuntun mereka pada pemahaman yang diinginkan, (Yuliana, Tasari, \& Wijayanti, 2017). Begitu juga Eggen \& Kauchak (2012) menyatakan dukungannya bahwa GDL merupakan salah satu model mengajar dimana guru memberi contoh-contoh topik spesifik kepada peserta didik dan memandunya untuk memahami topik tersebut.

Atas dasar fakta dan review dari beberapa sumber yang dikemukakan di atas, peneliti tertarik berkolaborasi dengan guru ekonomi untuk menerapkan model pembelajaran GDL melalui metode Penelitian Tindakan Kelas (PTK). Dasar penerapan model GDL pada mata pelajaran ekonomi juga sejalan dengan Permendiknas Nomor 22 Tahun 2016 (Bab 3 hal. 3), yang menyebutkan bahwa untuk memperkuat pelaksanaan pembelajaran dengan pendekatan ilmiah (scientific) pada Kurikulum K13 perlu diterapkan pembelajaran berbasis penyingkapan/penelitian (discovery/inquiry learning) (BSNP-Indonesia, 2016). Sedangkan melalui PTK diharapkan guru ekonomi mendapat pengalaman langsung tentang langkah-langkah penerapan model GDL. Selain itu kegiatan PTK mengajak guru untuk bisa menghayati bagaimana pelaksanaan model GDL di dalam kelas dengan cara "belajar mengalami" (experiential learning) dan belajar dengan melakukan/berbuat (learning by doing). Guru ekonomi dalam PTK akan merefleksi apa yang sudah dilakukan, apa yang sudah dialaminya, dan apa yang harus dilakukan untuk menyempurnakan kekurangan model GDL yang digunakan untuk membimbing peserta didiknya belajar ekonomi.

Sanjaya (2016) mendefinisikan PTK sebagai proses pengkajian masalah pembelajaran di kelas melalui refleksi diri dalam upaya untuk memecahkan masalah tersebut dengan cara melakukan berbagai tindakan yang terencana dalam situasi nyata serta menganalisis setiap pengaruh dari perlakuan tersebut. Kemmis dan Taggart (1992) dalam Hamid (2009) menyatakan, bahwa konsep Penelitian Tindakan (Action Research) dikembangkan pertama kali oleh Kurt Lewin pada tahun 1946 dan pendekatan satu-satunya yang dapat dilakukan dalam Penelitian Tindakan adalah pendekatan kolaboratif yang sangat penting untuk mewujudkan keberhasilan kelompok melalui latihan berfikir kritis anggota kelompok. Menurut Raka Joni (1997) dalam Hamid (2009), prinsip kolaborasi (kerjasama) yang diterapkan dalam PTK, bertujuan untuk menciptakan hubungan kerja kesejawatan. Guru dan dosen LPTK diharapkan dapat bekerjasama (kolaborasi) dalam; melakukan penelitian, melakukan tindakan, melakukan observasi terhadap efek-efek yang ditimbulkan oleh tindakan, melaksanakan analisis data, melakukan interpretasi data, dan menarik 
kesimpulan. Jadi, guru dan dosen LPTK merupakan suatu tim yang kedudukannya sama, setara, dan bersifat demokratis.

PTK merupakan cara yang sistematis yang dapat membantu guru untuk meningkatkan kompetensi pedagogisnya dengan cara melakukan refleksi langsung terhadap kualitas pelaksanaan pembelajaran model GDL serta hasil belajar peserta didik. Upaya meningkatkan kompetensi pedagogisnya secara intensif ini sesuai dengan amanat Undang-undang No. 14 Tahun 2005 tentang Guru dan Dosen. Kompetensi pedagogis sebagaimana dimaksud dalam undang-undang tersebut merupakan kemampuan Guru dalam pengelolaan pembelajaran peserta didik yang sekurang-kurangnya meliputi; a) pemahaman wawasan atau landasan kependidikan; b) pemahaman terhadap peserta didik; c) pengembangan kurikulum atau silabus; d) perancangan pembelajaran; e) pelaksanaan pembelajaran yang mendidik dan dialogis; f) pemanfaatan teknologi pembelajaran; g) evaluasi hasil belajar; dan h) pengembangan peserta didik untuk mengaktualisasikan berbagai potensi yang dimilikinya, (Sudrajat, 2009).

Kelebihan model GDL dan PTK dalam memecahkan masalah pembelajaran di kelas dan meningkatkan hasil belajar juga telah dibuktikan oleh beberapa hasil penelitian terdahulu, antara lain; (a) dapat meningkatkan representasi matematis dan percaya diri siswa, (Muhamad, 2016); (b) dapat meningkatkan hasil belajar siswa (Mariza Fitri, 2015); (c) pembelajaran melalui model GDL dengan menggunakan pendekatan scientific mengalami peningkatan pada setiap siklusnya, (Anesti, 2016); (d) dapat meningkatkan pemahaman konsep matematis siswa (Mawaddah dan Maryanti, 2016); (e) Persepsi sebagian besar peserta memiliki pandangan positif, mereka menyatakan bahwa melalui game berbasis media edutainment dengan menggunakan pendekatan penemuan terbimbing dalam proses pembelajaran Matematika membuat siswa tidak takut untuk menemukan konsep matematika secara independen ketika mereka belajar melalui permainan game, (Ardani dan Setyaningrum, 2018); (f) terdapat peningkatan pemahaman konsep peserta didik setelah menggunakan perangkat pembelajaran berbasis guided discovery learning, (Dyah dan Wiyatmo, 2018).

Kesimpulannya, PTK dan GDL adalah bagian tak terpisahkan dari kegiatan pembelajaran ekonomi di kelas. Melalui kegiatan PTK, guru ekonomi akan berusaha memecahkan masalah-masalah praktis dalam proses pembelajaran ekonomi termasuk upaya meningkatkan kompetensi pedagogisnya sehingga dapat mengantar peserta didik menuju capaian hasil belajar yang maksimal.

\section{METODE PENELITIAN}

Penelitian dilaksanakan pada bulan Agustus sampai Oktober tahun pelajaran 2019/2020 di kelas X IPS-3 dan X IPS-4 SMAN 3 Palembang. PTK dilakukan dalam 2 siklus (8 kali pertemuan) dengan prosedur seperti di ilustrasikan di gambar 1. Setiap siklus meliputi; perencanaan, tindakan, observasi dan refleksi. Perencanaan merupakan tahap merancang kegiatan dan penentuan strategi penerapan model GDL. Tahap pengamatan, meliputi merekam data/kejadian selama proses penerapan strategi yang telah 
direncanakan dan mencatatnya ke dalam lembar observasi kegiatan dan reaksi yang terjadi selama penerapan model GDL. Tahap refleksi, guru ekonomi dan peneliti mendiskusikan kekuatan dan kelemahan selama penerapan model GDL pada siklus I dan selanjutnya menentukan apa yang perlu diperbaiki pada siklus II dan seterusnya sampai ditemukan model GDL yang dapat membantu peserta didik memahami konsep ekonomi dengan baik dan menjadikan GDL model pembelajaran yang menyenangkan bagi pendidik dan peserta didik.

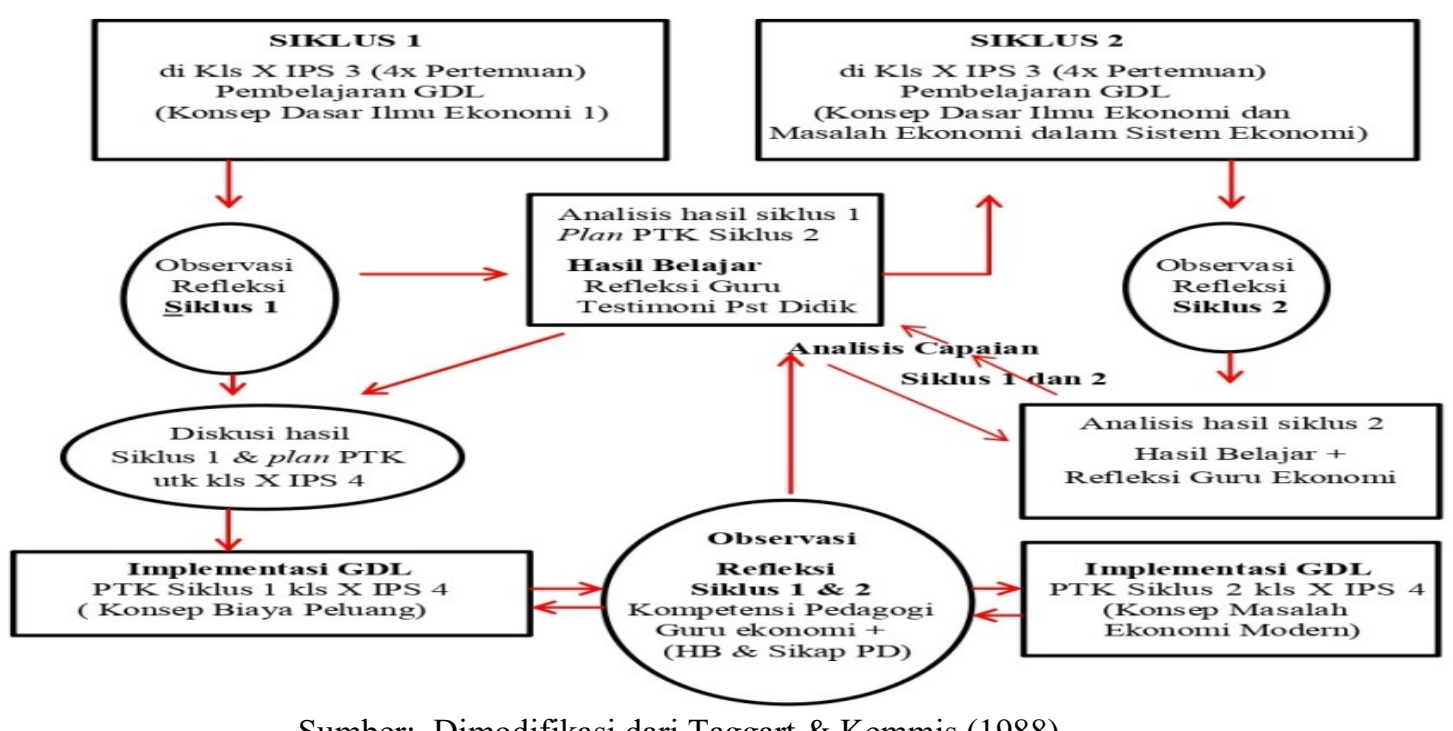

Sumber: Dimodifikasi dari Taggart \& Kemmis (1988)

Gambar 1. prosedur pelaksanaan penelitian

Setiap selesai 1 siklus dan ada peningkatan hasil belajar, guru ekonomi juga melakukan PTK serupa namun di kelas berbeda (disebut sebagai kelas bayangan), yaitu kelas X IPS-4. Pada kelas X IPS-4 guru juga menerapkan PTK dengan model pembelajaran GDL yang sama sebanyak 2 siklus ( $8 \mathrm{x}$ pertemuan). Kegiatan ini dilakukan untuk memastikan bahwa kompetensi pedagogis guru benar-benar telah meningkat setelah berkolaborasi dengan peneliti pada penerapan PTK di kelas X IPS-3.

Hipotesis tindakan yaitu; "Kompetensi pedagogis pendidik dan hasil belajar peserta didik dapat ditingkatkan melalui penerapan model Guide Discovery Learning dalam mata pelajaran ekonomi". Instrumen pengumpulan data menggunakan; Tes hasil belajar, lembar observasi, dan wawancara. Tes diberikan dalam bentuk soal Multiple Choice dan essay. Data diklasifikasikan dalam 2 katagori utama, yaitu;

1) Data hasil belajar peserta didik kelas X IPS-3; Untuk memperkuat validitas data hasil belajar, maka data ini didukung oleh data dari; Jurnal refleksi guru ekonomi terhadap proses pembelajaran di kelas X IPS-3, dan Wawancara dengan peserta didik di kelas X IPS-3 setiap selesai pembelajaran.

2) Data peningkatan kompetensi pendidik dalam proses pembelajaran dengan GDL, bersumber dari lembar observasi proses, hasil belajar peserta didik, serta sikap peserta didik di kelas X IPS-4. 


\section{Analisis Data}

1) Untuk mengetahui peningkatan hasil belajar bidang kemampuan potensi akademik, digunakan rumus;

Jumlah peserta didik yang menjawab benar soal

Total jumlah peserta didik

2) Untuk mengetahui peningkatan hasil belajar bidang kemampuan potensi non- akademik, digunakan rumus;

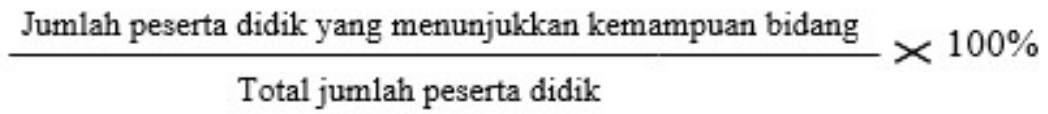

Selanjutnya data yang diperoleh dikonversi dengan pedoman di tabel 1 .

Tabel 1. Pedoman Konversi Nilai Peningkatan Hasil Belajar

\begin{tabular}{cc}
\hline Pedoman Peningkatan & Nilai Peningkatan \\
\hline $81 \%-100 \%$ & Sangat baik \\
$61 \%-80 \%$ & Baik \\
$40 \%-60 \%$ & Cukup \\
$<40 \%$ & Kurang \\
\hline
\end{tabular}

3) Analisis Kompetensi Pedagogis Guru Ekonomi di Kelas X IPS-4

Pedoman observasi terhadap tiga komponen kompetensi pedagogis dalam mengajar di kelas X IPS-4 ditampilkan di tabel 2.

Tabel 2. Pedoman Observasi Kompetensi Pedagogis Pendidik

\begin{tabular}{cll}
\hline No. & \multicolumn{1}{c}{ Komponen } & \multicolumn{1}{c}{ Indikator } \\
\hline 1 & Merancang & a. Menerapkan Teori belajar dan \\
pembelajaran GDL. & pembelajaran \\
& & $\begin{array}{l}\text { b. } \text { Strategi pembelajaran berdasarkan } \\
\text { karakteristik peserta didik, kompetensi }\end{array}$ \\
& & yang dicapai, dan materi ajar \\
2 & Melaksanakan & a. Menata latar (setting) pembelajaran \\
pembelajaran & b. Melaksanakan pembelajaran yang kondusif. \\
Mengembangkan & a. Memfasilitasi peserta didik untuk \\
peserta didik untuk & mengembangkan berbagai potensi \\
mengaktualisasikan & akademik \\
berbagai potensi yang & b. Memfasilitasi peserta didik untuk \\
dimilikinya & mengembangkan berbagai potensi non- \\
& & akademik
\end{tabular}

Observer akan memberikan penilaian terhadap kompetensi guru ekonomi dengan memberikan checklist pada pernyataan Ya atau Tidak untuk setiap butir penilaian pada rubrik observasi yang menunjukkan munculnya indikator komponen kompetensi. Selanjutnya nilai tersebut dikonversikan agar diketahui nilai peningkatan kompetensi pedagogis guru ekonomi dalam menerapkan model GDL seperti pada tabel 3. 
Tabel 3. Pedoman Konversi Nilai Peningkatan Kompetensi Pedagogis

\begin{tabular}{cc}
\hline Pedoman Peningkatan & Nilai Peningkatan \\
\hline 2 Indikator tampak & Sangat baik \\
1 Indikator tampak & Baik \\
Indikator tidak tampak & Tidak meningkat \\
\hline Sumber : Diadaptasi dari Arikunto (2006) &
\end{tabular}

Data kualitatif diamil dari seperti jurnal refleksi guru ekonomi dan hasil wawancara dengan peserta didik (testimoni), menggunakan model analisis interaktif data yang terbagi dalam 3 tahap analisis, yaitu; data reduction, data display, dan conclusion drawing (Miles \& Huberman, 1984).

\section{HASIL PENELITIAN DAN PEMBAHASAN}

\section{Hasil Belajar Peserta Didik di Kelas X IPS-3}

Hasil belajar peserta didik dibagi menjadi dua katagori, yaitu bidang kemampuan potensi dan bidang kemampuan potensi non- akademik. Dalam gambar 1 adalah hasil belajar bidang kemampuan potensi akademik peserta didik di kelas X IPS-3 setelah mengikuti pembelajaran ekonomi dengan model GDL. Setelah pembelajaran ekonomi dengan model GDL pada siklus 1 dan 2, terdapat 4 kemampuan potensi akademik peserta didik di kelas X IPS-3 yang terkatagori Sangat baik, yaitu bidang kemampuan; 1) Pengetahuan ekonomi (mengungkapkan fakta-fakta dan istilah); 2) Pemahaman konsep ekonomi (metode dan prosedur); 3) Penerapan konsep ekonomi (ketrampilan memecahkan masalah ekonomi); dan 4) Ketrampilan berpikir (ketrampilan berpikir ilmiah dalam menjelaskan hubungan antar fakta dan konsep ekonomi). Pada bidang kemampuan Penerapan (konsep dan prinsip ekonomi) serta kemampuan (berpikir kritis), kemampuan peserta didik terkatagori Baik. Sedangkan ketrampilan pemahaman konsep ekonomi yang diukur dari kemampuan membuat grafik dan mengolah angka, peserta didik terkatagori Cukup (tingkat capaian 60\%).

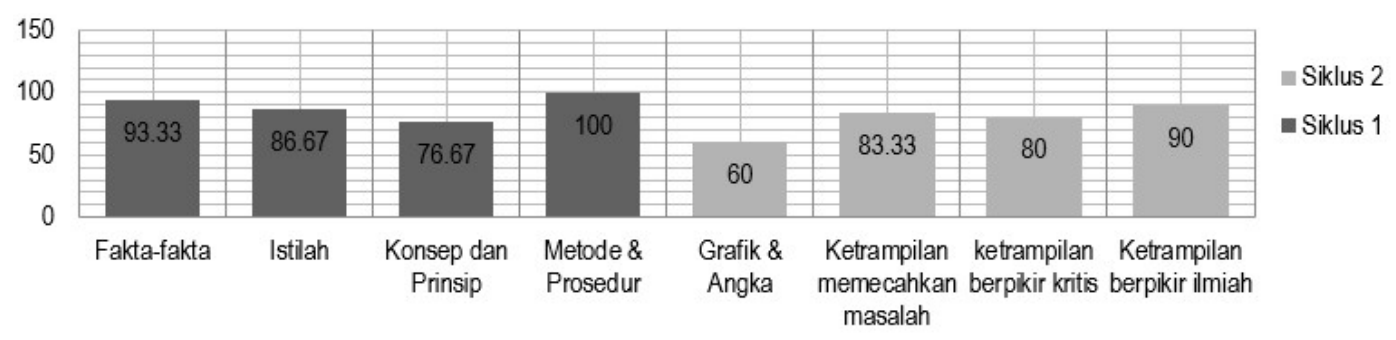

Gambar 1. Hasil Belajar Peserta Didik X IPS-3 Bidang Kemampuan Potensi Akademik

Selanjutnya pada gambar 2 diinformasikan terjadi juga peningkatan kemampuan potensi non-akademik peserta didik di kelas X IPS-3 dari siklus 1 ke siklus 2. Untuk hasil belajar bidang kemampuan potensi non-akademik, sejak siklus 1 peserta didik di kelas X IPS-3 telah memiliki potensi nonakademik dengan katagori Baik dan Sangat Baik. Pada siklus ke 2 terjadi peningkatan potensi non akademik hingga 100\% (Sangat Baik). Informasi 
yang terdapat pada gambar 2, menunjukkan bahwa proses pembelajaran ekonomi dengan menggunakan model GDL mampu meningkatkan hasil belajar bidang kemampuan non-akademik dengan sangat baik, khususnya bagi kemampuan berkomunikasi yang meningkat sebesar 30\% dan Minat Pribadi peserta didik terhadap pelajaran ekonomi dari siklus 1 ke siklus 2 naik sebesar $10 \%$.

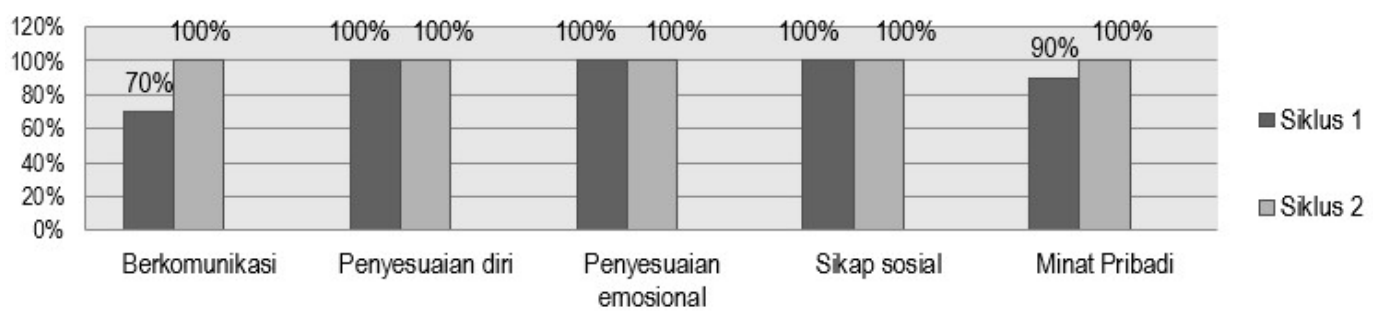

Gambar 2. Hasil Belajar Peserta Didik X IPS-3 Bidang Kemampuan Potensi Non-Akademik

Berdasarkan nformasi yang ditunjukkan dalam gambar 1 dan 2, dapat disimpulkan bahwa model GDL dapat meningkatkan hasil belajar ekonomi peserta didik dalam bidang kemampuan akademik dan non akademik. Pada bidang akademik terjadi peningkatan kemampuan pengetahuan sampai kemampuan berpikir (berpikir kritis dan berpikir ilmiah). Pada bidang nonakademik kemampuan peserta didik juga meningkat baik di tingkat personal maupun interpersonal. Hasil belajar ekonomi yang meningkat setelah penerapan model pembelajaran GDL juga disebabkan karena adanya lingkungan belajar yang kondusif dan guru memberikan motivasi dan bimbingan sehingga peserta didik dapat mengembangkan potensi dan kreativitasnya melalui interaksi belajar dan pembelajaran yang dikelola guru. Pernyataan ini berdasarkan analisis hasil pengamatan (observasi) guru ekonomi yang difokuskan pada 5 komponen terkait pelaksanaan model pembelajaran GDL. Tujuan observasi untuk melihat, menilai, dan merefleksi peristiwaperistiwa belajar yang terjadi selama pembelajaran dalam 2 siklus (8x pertemuan), yaitu siklus 1 (pertemuan 1 s.d 4) dan siklus 2 (pertemuan 5 s.d 8). Refleksi tersebut dicatat dalam "Jurnal Refleksi Guru" (JRG). Ada 8 JRG yang dihasilkan dari pengamatan selama 8 x pertemuan tersebut. Berikut ini adalah kesimpulan dari hasil analisis terhadap 8 JRG ekonomi;

1) Selama kegiatan pembelajaran dengan model GDL, guru selalu menggunakan alat peraga, media pembelajaran, serta LKS, dan peserta didik ikut menggunakan alat-alat pembelajaran tersebut.

2) Guru selalu berperan sebagai fasilitator, motivator, model, dan membimbing tugas-tugas belajar peserta didik di dalam kelas.

3) Guru seringkali memberi pertanyaan-pertanyaan untuk meninjau pemahaman peserta didik, memberikan umpan balik terhadap jawabannya, dan menggunakan kartu benar-salah untuk memeriksa pemahaman peserta didik terhadap materi ekonomi, serta memberikan reward jika peserta didik berprestasi atau menunjukkan sikap positif dalam pembelajaran, 
4) Peserta didik aktif bekerjasama dalam kelompok, antusias mengikuti kegiatan belajar ekonomi, dan pada siklus ke-2 semakin percaya diri untuk bertanya dan mengemukakan pendapat.

5) Hal negatif yang dirasakan oleh observer adalah suara guru yang kurang keras, sehingga instruksi yang diberikan kadang tidak jelas dan harus dilakukan berulang kali atau instruksi kegiatan belajar diberikan melalui Liquid Crystal Display Projector (proyektor LCD).

Selain berdasarkan hasil analisis JRG di atas, informasi tentang adanya peningkatan hasil belajar ekonomi juga didukung oleh hasil analisis data terhadap testimoni peserta didik di kelas X IPS-3. Testimoni ini adalah refleksi peserta didik selama mereka mengikuti proses pembelajaran ekonomi dengan model GDL. Setiap kali selesai pembelajaran, guru ekonomi sebagai observer di kelas X IPS-3, meminta 3 orang peserta didik yang dipilih secara acak untuk memberikan testimoninya selama mereka mengikuti proses pembelajaran di kelas. Kegiatan ini direkam dalam video untuk memudahkan peneliti dan guru menganalisis isi testimoni tersebut. Kami mendapatkan 24 testimoni, dan berikut ini adalah kesimpulan dari 24 testimoni tersebut;

1) Peserta didik dapat mengikuti tahapan model pembelajaran Guide Descovery learning dengan baik dan penjelasan guru disertai pertanyaan atau contoh-contoh yang sederhana sehingga mudah dipahami.

2) Peserta didik lebih percaya diri dalam berkomunikasi dengan guru atau teman sekelasnya terkait tugas-tugas belajar yang diberikan, karena guru membimbing setiap tahap kegiatan belajar.

3) Aktivitas belajar menyenangkan, mudah diikuti, dan simpel, karena diperagakan dengan alat peraga sederhana dan beragam, seperti; uang pecahan RP.50.000,- untuk mengidentifikasi konsep keinginan dan kebutuhan; gunting dan kertas yang digunakan peserta didik untuk memahami masalah kelangkaan barang, biaya peluang, dan kegiatan produksi.

4) Peserta didik memberikan saran agar suara guru lebih keras saat memberikan instruksi kegiatan belajar dan perbanyak kegiatan quiz dan game.

Hasil analisis data JRG dan testimoni peserta didik terkait pelaksanaan pembelajaran ekonomi menunjukkan bahwa dalam interaksi belajar mengajar dengan model GDL, peserta didik termotivasi belajarnya karena guru berkreasi dengan beragam media pembelajaran ekonomi sehingga aktivitas belajar lebih menyenangkan dan lebih mudah memahami konsep-konsep ekonomi yang dibahas. Selain itu alat bantu mengajar seperti gunting dan kertas sangat efektif digunakan untuk memahami bagaimana hubungan antara kelangkaan dan biaya peluang dalam kegiatan produksi serta melatih bagaimana mereka harus membuat keputusan yang efisien di antara beberapa pilihan. Kegiatan ini juga memberikan pengalaman lebih konkret, memotivasi serta mempertinggi daya serap dan daya ingat pebelajar dalam belajar. Keterbatasaan guru pada volume suara yang tidak bisa ditingkatkan lagi dapat diimbangi oleh alat bantu mengajar yang digunakan guru dan peserta didik. Terkait fakta ini Falahudin (2014) menyatakan penggunaan media pembelajaran pada tahap orientasi pengajaran akan sangat membantu keefektifan proses pembelajaran dan penyampaian pesan dan isi pelajaran. 
Pemberian reward dalam pembelajaran model GDL juga merupakan salah satu usaha pendidik untuk memotivasi dan meningkatkan hubungan interpersonal dengan peserta didik supaya mereka mau belajar dan berusaha untuk meningkatkan ketrampilan berpikir mereka dari LOTS menuju HOTS. Dalam hal ini Rakhmat (2012) menjelaskan bahwa seseorang lebih menyenangi orang lain yang memberi penghargaan atau ganjaran berupa pujian, bantuan, dan dorongan moral. Reward ini ini juga terbukti efektif untuk mencapai hasil belajar yang kita inginkan. Hasil analisis testimoni yang menyarankan agar guru memperbanyak game dan quiz, membuktikan bahwa peserta didik menyukai penghargaan dan meningkatkan percaya diri mereka.

\section{Kompetensi Pedagogis Guru Ekonomi}

Hasil refleksi guru dalam JRG menunjukkan bahwa guru ekonomi secara teori telah memahami sintak dari model GDL dengan baik. Namun untuk memastikan bahwa kompetensi pedagogis guru benar-benar telah meningkat, maka setelah berkolaborasi dengan peneliti pada penerapan PTK di kelas X IPS-3, guru ekonomi juga melaksanakan pembelajaran dengan model GDL secara mandiri di kelas X IPS-4 dan peneliti sebagai observernya. Observasi menggunakan instrumen Penilaian Kompetensi Pedagogis Guru Ekonomi (Tabel 2).

Acuan utama pengembangan instrumen observasi adalah Undang-undang No. 14 Tahun 2005 tentang Guru dan Dosen, yang menyebutkan bahwa kompetensi pedagogis adalah "kemampuan mengelola pembelajaran peserta didik", (Menteri Hukum dan Hak Asasi Manusia Republik Indonesia, 2005). Selanjutnya Depdiknas (2004) menyebut kompetensi ini dengan kompetensi pengelolaan pembelajaran dan tercermin dari indikator (1) kemampuan merencanakan program belajar mengajar, (2) kemampuan melaksanakan interaksi atau mengelola proses belajar mengajar, dan (3) kemampuan melakukan penilaian, (Direktorat Tenaga Kependidikan Depdiknas, 2004). Instrumen observasi ini juga merujuk pendapat Budiwati (2010) yang menyebutkan secara substantif kompetensi pedagogis guru mencakup kemampuan pemahaman terhadap peserta didik, perancangan dan pelaksanaan pembelajaran, evaluasi hasil belajar, dan pengembangan peserta didik untuk mengaktualisasikan berbagai potensi yang dimilikinya, (Budiwati \& Permana, 2010). Selanjutnya Akhmad Sudrajat menyebutkan 7 aspek kompetensi pedagogis guru, yaitu; 1) menguasai karakteristik peserta didik, 2) menguasai teori belajar dan prinsip-prinsip pembelajaran yang mendidik, 3) pengembangan kurikulum, 4) kegiatan pembelajaran yang mendidik, 5) pengembangan potensi peserta didik, 6) komunikasi dengan peserta didik, 7) penilaian dan evaluasi (Sudrajat, 2012).

Berdasarkan undang-undang dan beberapa sumber di atas, kompetensi pedagogis guru ekonomi dalam penelitian ini dibagi dalam tiga komponen kompetensi, yaitu; 1) Merancang pembelajaran GDL; 2) Melaksanakan pembelajaran; 3) Mengembangkan peserta didik untuk mengaktualisasikan berbagai potensi yang dimilikinya. Setiap komponen memiliki 2 indikator pengukuran kompetensi pedagogis (Tabel 2). Hasil analisis data observasi yang bersumber dari 8x laporan kegiatan pengamatan di kelas X IPS-4 membuktikan terjadi peningkatan kompetensi pedagogis guru dari siklus 1 ke siklus 2 yang 
tergambar dalam aktivitas guru yang muncul berdasarkan indikator yang telah ditetapkan (Tabel 6 pada lampiran). Setelah dikonversi menggunakan tabel 3, diperoleh hasil nilai peningkatan pedagogis guru ekonomi adalah; 1) kemampuan merancang pembelajaran GDL terkatagori Baik ; 2) kemampuan melaksanakan pembelajaran dalam hal menata latar (setting) pembelajaran sudah Baik, dan kemampuan melaksanakan pembelajaran yang kondusif terkatagori Sangat baik; 3) kemampuan mengembangkan peserta didik untuk mengaktualisasikan potensi akademik yang dimilikinya sudah Baik, dan kemampuan guru mengembangkan aspek non-akademik peserta didik terkatagori Sangat baik.

Kemampuan guru untuk membuat situasi pembelajaran yang kondusif ini menunjukkan bahwa guru telah memiliki kompetensi pedagogis yang semakin baik dalam melaksanakan pembelajaran ekonomi seperti yang dibuktikan dari hasil observasi. Pendapat Budiwati memperkuat hasil penelitian ini, dimana disebutkan bahwa dengan adanya kompetensi pedagogis yang baik, dapat memungkinkan terjadinya pengelolaan pembelajaran yang mendidik dan dialogis, (Budiwati \& Permana, Perencanaan Pembelajaran Ekonomi, 2010). Kesimpulannya, hasil observasi ini menunjukkan kolaborasi melalui PTK antara peneliti dan guru ekonomi pada saat menerapkan model GDL di kelas X IPS-3 terbukti dapat meningkatkan kompetensi pedagogis guru yang ditunjukkan melalui kemampuannya menerapkan model GDL secara mandiri di kelas X IPS-4.

\section{Hasil Belajar Peserta Didik di Kelas X IPS-4}

Peningkatan kompetensi pedagogis guru ekonomi yang telah dibuktikan berdasarkan hasil analisis data observasi penerapan model GDL di kelas X IPS-4, diikuti juga dengan peningkatan hasil belajar ekonomi dan sikap peserta didik dalam pembelajaran ekonomi di kelas. Gambar 3 menunjukkan pada siklus 1 peserta didik yang mencapai KKM hanya 10 orang $(33.33 \%)$ dengan predikat Cukup. Sedangkan 20 orang lainnya (66.67\%) belum mencapai KKM (nilai 76). Namun pada siklus ke 2, ada peningkatan hasil belajar ekonomi di kelas X IPS 4, yaitu terdapat 13 peserta didik (43.33\%) mencapai nilai dengan katagori Amat baik, 17 orang (56.67\%) dengan katagori nilai Baik, dan tidak ada peserta didik yang mendapat nilai dengan katagori cukup maupun kurang.

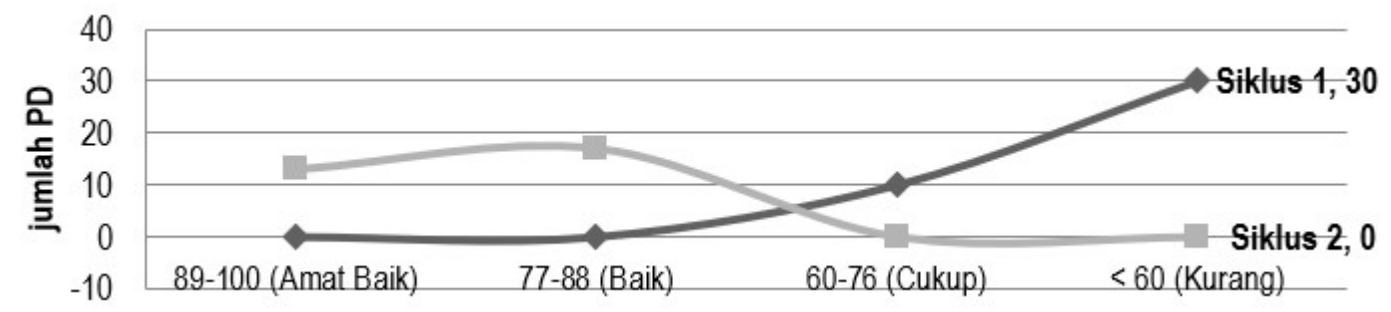

Gambar 3. Hasil Belajar Peserta Didik X IPS 4

Selanjutnya informasi pada gambar 4 menggambarkan peningkatan yang terjadi pada sikap peserta didik terhadap mata pelajaran ekonomi setelah guru menerapkan model pembelajaran GDL. Sikap peserta didik yang terlihat pada gambar 4 meningkat dari siklus 1 ke siklus 2 . Peningkatan sikap terjadi pada semua indikator pengukuran sikap. Nilai peningkatan sikap tertinggi pada 
aspek kejujuran peserta didik dalam menjawab permasalahan ekonomi yang diberikan. Kejujuran tersebut menunjukkan bahwa pertanyaan-pertanyaan guru selama proses pembelajaran dijawab berdasarkan pemahaman mereka terhadap materi yang ditanyakan guru. Kondisi ini dapat diartikan bahwa kepercayaan diri peserta didik menjadi lebih baik setelah belajar ekonomi dengan model GDL. Apabila dihubungkan dengan kesimpulan hasil pengamatan kompetensi pedagogis guru ekonomi yang meningkat dari siklus 1 ke siklus 2 dimana guru sudah Baik mengembangkan peserta didik untuk mengaktualisasikan potensi akademik yang dimilikinya, dan terkatagori Sangat baik untuk aspek non-akademik, maka dapat disimpulkan bahwa kompetensi pedagogis guru ekonomi telah mempengaruhi kepercayaan diri peserta didik akan pengetahuannya dalam ilmu ekonomi. Selain berpengaruh terhadap kejujuran peserta didik dalam menjawab permasalahan yang diberikan, mereka juga menjadi peduli dalam kegiatan pembelajaran dan memiliki tanggung jawab sosial yang baik dalam menyelesaikan tugas-tugas yang diberikan guru.

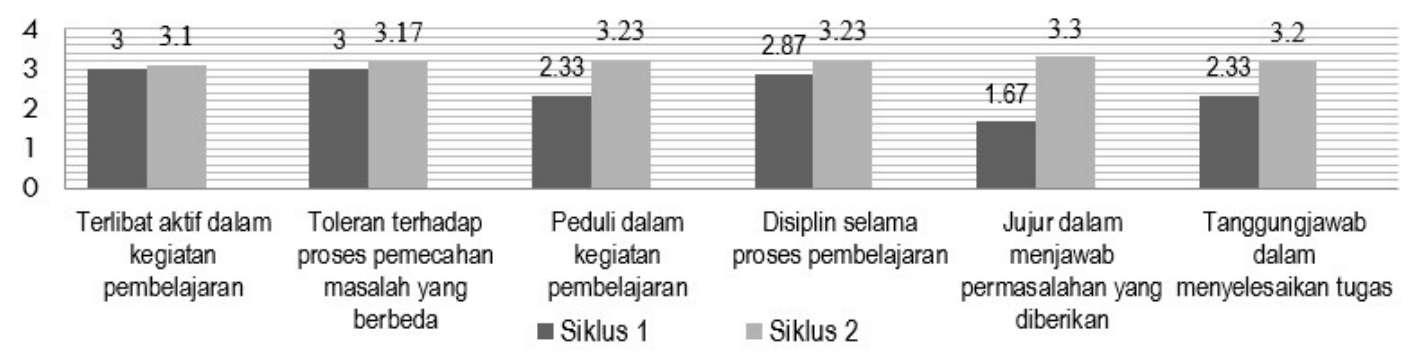

Gambar 4. Sikap Peserta Didik Setelah Pembelajaran di Kelas X IPS 4

Model pembelajaran GDL yang diterapkan melalui metode PTK terbukti dapat meningkatkan kompetensi pedogogik pendidik ekonomi dalam pembelajaran dan meningkatkan hasil belajar peserta didik. Selain tujuan penelitian telah tercapai, pada saat pengamatan proses pembelajaran ekonomi dan berdasarkan hasil analisis data, peneliti melihat pentingnya peranan hubungan interpersonal terutama pada saat ketiga komponen penelitian ini diaktualisasikan dalam proses pembelajaran ekonomi. Hubungan interpersonal adalah hubungan yang terdiri dari dua orang atau lebih yang saling tergantung satu sama lain dan menggunakan pola interaksi yang konsisten (Dian \& Srifatmawati, 2012). Interaksi personal yang baik antara guru dan peserta didik akan menciptakan kondisi pembelajaran ekonomi dengan GDL menjadi kondusif sehingga peserta didik selalu merespon stimulus yang diberikan guru.

Untuk melihat bagaimana peranan hubungan interpersonal dalam mendukung keberhasilan penerapan model GDL, kita dapat melihat kembali konsep tiga komponen dalam penelitian ini. Pertama PTK. Salah satu ciri khas PTK adalah adanya kolaborasi (kerjasama) antara praktisi (guru, kepala sekolah, siswa, dlI) dan peneliti (dosen, widyaiswara) dalam pemahaman, kesepakatan tentang permasalahan, pengambilan keputusan yang akhirnya melahirkan kesamaan tindakan (action) (Depdiknas Dirjen Peningkatan Mutu Pendidik dan Tenaga Kependidikan Direktorat Profesi Pendidik, 2007). Perlunya kolaborasi dalam PTK ini adalah untuk mendukung objektivitas pengamatan selama berlangsungnya PTK (Kunandar, 2008). Kolaborasi 
(kerjasama) akan timbul apabila orang menyadari bahwa mereka mempunyai kepentingan-kepentingan yang sama dan pada saat yang bersamaan mempunyai pengetahuan dan pengendalian terhadap diri sendiri (Suranto, 2011). Agar kolaborasi berhasil mencapai objektivitas pengamatan dan penyelesaian masalah maka perlu adanya hubungan interpersonal yang baik antara pelaksana PTK. Ke dua model GDL. Ciri utama dari model GDL adalah adanya unsur "membimbing/ bimbingan". Kegiatan ini menunjukkan bahwa model pembelajaran ini juga memerlukan kerjasama dan komunikasi antara guru dan dosen, guru dan peserta didik, serta peserta didik dengan peserta didik lainnya dalam kelas tersebut. Eggen (2012:17) dalam (Sarumaha, 2018) menyatakan, GDL adalah satu pendekatan mengajar dimana guru memberi siswa contoh-contoh topik spesifik dan memandu (membimbing) siswa untuk memahami topik tersebut. Agar kegiatan membimbing berjalan dengan baik, maka diperlukan kedekatan yang harmonis bersifat dua arah (hubungan interpersonal) sehingga permasalahan yang rumit dapat berbuah positif. Ke tiga, Pendidik. Salah satu tugas utama pendidik profesional adalah "membimbing". Mengutip Undang-undang Nomor 14 tahun 2006 tentang guru dan dosen, Bab 1 Pasal 1 menjelaskan, bahwa guru adalah pendidik profesional dengan tugas utama mendidik, mengajar, membimbing, mengarahkan, melatih, menilai, dan mengevaluasi peserta didik. Sanjaya (2016) menjelaskan, membimbing adalah proses mengarahkan siswa sesuai dengan potensi yang dimilikinya baik yang berkaitan dengan minat maupun bakat seseorang. Sebagai seorang pembimbing dalam proses pembelajaran, guru harus memiliki hubungan interpersonal yang baik dengan peserta didik agar dapat membimbing mereka yang mengalami masalah pembelajaran ekonomi.

Pentingnya hubungan interpersonal juga telah diungkapkan sebelumnya oleh Ismail dan Awang (2004) yang menyatakan bahwa dengan hubungan interpersonal dalam kegiatan belajar akan membiasakan peserta didik berdialog dan menganalisis masalah ekonomi dari yang mudah ke sulit serta dapat melatih kemampuannya untuk membuat keputusan bijak dan bertanggungjawab. Selain itu lanjutnya dalam proses pembelajaran, sebaiknya pendidik dan peserta didik selalu menggunakan istilah-istilah ekonomi dan bahasa ekonomi yang jelas dan tepat. Ketika berkomunikasi kita tidak hanya menyampaikan isi pesan, tetapi juga menentukan kadar hubungan interpersonal. Banyak faktor yang mempengaruhi hubungan interpersonal. Terkait dengan pembahasan hasil penelitian ini, ada dua faktor penting yang mempengaruhi hubungan interpersonal dalam proses pembelajaran GDL, yaitu adanya komunikasi yag efektif dan ganjaran (reward) yang diberikan guru ekonomi kepada peserta didik yang menunjukkan sikap positif selama proses pembelajaran ekonomi. Rakhmat (2012) mengemukakan bahwa komunikasi akan efektif bila pertemuan antara pemangku kepentingan terbangun dalam situasi komunikatif-interaktif dan menyenangkan. Kondisi ini sangat ditentukan oleh validitas informasi yang disampaikan dan keterlibatan dalam memformulasikan ide atau gagasan secara bersama (Rakhmat, 2012). Jika bimbingan yang diberikan guru efektif melalui model pembelajaran yang tepat, maka materi yang dipelajari akan tersimpan lama dalam memori mereka.

Selain laporan keberhasilan mencapai tujuan penelitian seperti yang dijelaskan di atas, ada hambatan yang dihadapi dalam proses pembelajaran 
ekonomi dengan menggunakan model GDL, yaitu masalah waktu belajar yang tersedia. Waktu belajar 3 Jam Pelajaran (JP) untuk mata pelajaran ekonomi dipecah menjadi 1 JP dan 2 JP per minggu dan 1 JP setara 45 menit. Pembagian JP seperti ini cukup menyulitkan guru untuk mengalokasikan kegiatan belajar dengan model GDL, kaena mengubah gaya belajar peserta didik dari rote learning menjadi meaningfull learning membutuhkan beberapa tahapan dan contoh, sehingga waktu yang dibutuhkan minimal $2 \mathrm{JP} /$ pertemuan. Untuk itu disarankan kepada pihak sekolah agar pembagian jam belajar minimal 2JP/pertemuan, supaya pembelajaran aktif yang berpusat pada peserta didik lebih efektif.

\section{SIMPULAN}

Hasil belajar peserta didik pada mata pelajaran ekonomi dapat ditingkatkan dengan menggunakan model pembelajaran Guide Discovery Learning. Peningkatan hasil belajar ekonomi juga diikuti dengan peningkatan sikap dan kemampuan non-akademik lainnya meskipun kompetensi dalam bidang grafik dan angka masih terkatagori cukup. Selanjutnya, Kompetensi pedagogis pendidik dalam merencanakan, melaksanakan pembelajaran dan mengembangkan peserta didik untuk mengaktualisasikan berbagai potensi yang dimilikinya juga meningkat yang ditandai oleh kemampuannya untuk merefleksi pembelajaran GDL di kelas contoh (tindakan) dan melaksanakannya sendiri pada kelas yang berbeda. Hubungan interpersonal yang baik antara peneliti, pendidik, dan peserta didik sangat mempengaruhi mutu pembelajaran yang dilakukan.

\section{DAFTAR RUJUKAN}

Anesti, D. (2016). Penerapan model guided discovery learning dengan menggunakan pendekatan scientific untuk meningkatkan aktifitas dan hasil belajar siswa kelas VC subtema hubungan makhluk hidup dalam ekosistem SDN Kendalrejo 02 Talun Blitar. Etheses of Maulana Malik Ibrahim State Islamic University.

Ardani, R., \& Setyaningrum, W. (2018). Game-Based Edutainment Media using Guided Discovery Approach: What teachers say? The open access Journal of Physics: Conference Series (JPCS) provides a fast, versatile and cost-effective proceedings publication service.

Arikunto, S. (2006). Prosedur Penelitian: Suatu Pendekatan Praktik. Jakarta: PT. Rineka Cipta.

BSNP-Indonesia. (2016, Juni -). Retrieved Maret 25, 2020, from BSNPIndonesia Web site: https://bsnp-indonesia.org/wp-content/uploads/ 2009/06/Permendikbud_Tahun2016_Nomor022_Lampiran.pdf

BSNP-Indonesia. (2018, Agustus 25). Retrieved Maret 30, 2019, from https://ainamulyana.blogspot.com/2016/07/download-permendikbud-no- 
22-tahun-2016_14.html: https://drive.google.com/file/d/0B08C4Wiim KyfcWs 1RU4wb2tESG1pcF9uZk5QV1RlcUtKWkZN/view

Budiwati, N., \& Permana, L. (2010). Perencanaan Pembelajaran Ekonomi. Bandung: Laboratorium Pendidikan Ekonomi dan Koperasi, FEB, UPI.

Depdiknas Dirjen Peningkatan Mutu Pendidik dan Tenaga Kependidikan Direktorat Profesi Pendidik. (2007, Agustus). Penelitian Tindakan Kelas sebagai Pengembangan Profesi Guru. Retrieved April 12, 2020, from https://id.123dok.com/document/8ydpokgy-bagian-1-ptk-sebagaikegiatan-pengembangan-profesi-guru.html

Dian, W., \& Srifatmawati, M. (2012). Psikologi Sosial Individu \& Teori Psikologi Sosial. Jakarta: Salemba Humanika.

Direktorat Tenaga Kependidikan Depdiknas. (2004). Standar Kompetensi Guru. Jakarta.

Dyah, H. P., \& Wiyatmo, Y. (2018). Pengambangan Perangkat Pembelajaran Berbasis Guided Discovery Learning untuk Meningkatkan Pemahaman Konsep dan Kemampuan Kerja Sama Peserta Didik. E-Journal Pendidikan Fisika UNY, 18-28.

Eggen, P., \& Kauchak, D. (2012). Strategi dan Model Pembelajaran. Jakarta: PT Indeks.

Falahudun, I. (2014). Pemanfaatan Media dalam Pembelajaran. Jurnal Lingkar Widyaiswara, 104-117.

Hamid, A. A. (2009). Bab 2: Penelitian Tindakan. In Penelitian Tindakan, Penelitian Kelas, Penelitian Tindakan Kelas (p. 6). Yogyakarta: Pusat Pengembangan Instruksional Sains (P2IS).

Ismail, R., \& Awang, M. (2004). Isu-isu Dalam Pengajaran Ekonomi Asas. Kuala Lumpur: Pustaka Salam SDN. BHD.

Kementerian Pendidikan Nasional. Direktorat Jenderal Peningkatan Mutu Pendidik dan Tenaga Kependidikan. (2012, Juli). Retrieved Juli 21, 2019, from https://akhmadsudrajat.files.wordpress.com/2012/07/buku-2pedoman-pkg.pdf

Kunandar. (2008). Langkah Mudah Penelitian Tindakan Kelas sebagai Pengembangan Profesi Guru. Jakarta: PT Raja Grafindo Persada.

Mariza Fitri, D. (2015). Pengaruh Model Pembelajaran Discovery Learning Terhadap Hasil Belajar Siswa Pada Materi Pokok Suhu dan Kalor. Inovasi Pembelajaran Fisika, Vol 3, No 2. 
Mawaddah, S., \& Maryanti, R. (2016). Kemampuan Pemahaman Konsep Matematis Siswa SMP Dalam Pembelajaran Menggunakan Model Penemuan Terbimbing (Discovery Learning). Jurnal Pendidikan Matematika Universitas Lambung Mangkurat, Vol 4 (1), hal 76-85.

Menteri Hukum dan Hak Asasi Manusia Republik Indonesia. (2005, Desember 3). Undang-undang Republik Indonesia Nomor 14 Tahun 2015 Tentang Guru dan Dosen. Jakarta.

Miles, M., \& Huberman, A. (1984). Qualitative Data Analysis: a source of new methods. Beverly Hills: Sage Publications.

Muhamad, N. (2016). Pengaruh Metode Discovery Learning untuk Meningkatkan Representasi Matematis dan Percaya Diri Siswa. Jurnal Pendidikan Universitas Garut, Vol. 09; 9-22.

Pusat Penilaian Pendidikan, Kementerian Pendidikan dan Kebudayaan. (2019, -). Laporan Hasil Ujian Nasional. Retrieved Maret 25, 2020, from https://puspendik.kemdikbud.go.id/hasil-un/:-

Pyng, S. Y. (2011). Persepsi Terhadap Keberkesanan Pembelajaran Aktif dalam Pengajaran dan Pembelajaran Mata Pelajaran Ekonomi Asas Tingkatan Empat. Malaysia: Universiti Pendidikan Sultan Idris.

Rakhmat, J. (2012). Psikologi Komunikasi. Bandung: Remaja Rosdakarya.

Riduwan. (2010). Belajar Mudah Penelitian; untuk Guru-Karyawan dan Peneliti pemula. Bandung: Alfabeta.

Sanjaya, W. (2016). Penelitian Tindakan Kelas. Jakarta: Prenada Media.

Sarumaha, R. (2018). Upaya Meningkatkan Kemampuan Pemahaman Konsep Matematis Siswa SMAS Kampus Telukdalam Melalui Model Pembelajaran Penemuan Terbimbing. Jurnal Education and Development, Intitut Pendidikan Tapanuli Selatan, 70.

Sudrajat, A. (2009, Januari 16). Peraturan Pemerintah No. 74 Tahun 2008 tentang Guru. Retrieved Maret 25, 2020, from https://akhmadsudrajat. files.wordpress.com/2009/01/pp-no-74-tahun-2008-tentang-guru1.pdf

Sudrajat, A. (2012, Januari 29). Aspek dan Indikator Kompetensi Pedagogik Guru. Retrieved Juli 21, 2019, from https://akhmadsudrajat. wordpress.com/2012/01/29/kompetensi-pedagogilk-guru/

Suranto, A. (2011). Komunikasi Interpersonal. Yogyakarta: Graha Ilmu.

Taggart, R. M., \& Kemmis, S. (1988). The Action Research Planner. Victoria: Deakin University. 
Wilkins, A. R. (1990). An Inductive Model for Guided Discovery. In Model Lessons (p. 94). West Australia: Curtin University of Technology.

Yuliana, Tasari, \& Wijayanti, S. (2017). The Effectiveness of Guided Discovery Learning to Teach Integral Calculus for The Mathematics Student of Mathematics Education Widya Dharma University. Infinity; Journal of Mathemtics Education, 1-10. 
